\title{
CHILD OF ADDICTED PARENTS - THE OVERLOOKED MEMBER IN A FAMILY
}

\author{
Tatiana Dubayová
}

\begin{abstract}
Children of addicted parents often escape professional interventions and the social system, because their needs and the responses resulting from the failure to fulfil them are not diagnosed correctly. Although they are not typical recipients of special education interventions, we may take them as children with special needs in the emotional area even if though their symptoms are not necessarily evident. The aim of the paper is to help to understand the perception and behaviour of a child from a family with an addicted parent. Based on analyses of foreign research projects, we have summed up the specific features of such children, their most frequent responses and coping with difficulties. At the same time, we will try to outline the opportunities and challenges of the work with such children and the assistance that may help them compensate for the traumatic experiences from their childhood when they grow up.
\end{abstract}

\section{Keywords}

addicted individual, child at risk, child of an addicted parent, mental vulnerability

\section{Introduction}

Childhood free of violence, traumatic experiences and lived in a safe environment should be the priority number one of each society. Unfortunately, many children are currently growing up in conditions coming close to trauma even here, in peaceful and relatively conflict-free Europe. What is more, some of the children living with an addicted parents have been observed to show symptoms similar to those which are observed in soldiers when they witness war crimes - sleep disorders, anxiety, depression, flashbacks of traumatic experiences (AAETS, 2014).

Current estimates of children growing up with a parent addicted to alcohol or other addictive substances in European countries range from 5-30 \% (EMCDDA, 2010). The Columbia University's report states that nearly one quarter of child population in the United States of America lives in a household where at least one parent drinks alcohol or uses illegal drugs (CASA, 2005). However, the above statistics are not accurate, they 
were generated as an expert estimate rather than obtained based on actual research work. The number of children who have an experience with parental substance abuse is believed to be much bigger.

Vašek (2011) and other authors believe that these children are a part of the so-called risk group and if not provided specialised care in time, their development may be seriously impaired. But what does this classification mean and which interventions are relevant in such case? This is not that clear. I dare say that these children escape system solution and are omitted from all kinds of protective measures, if the parental abuse is within the boundaries that the people in their neighbourhood are willing to tolerate or if it is not also connected with violence that they can actually see.

For the purposes of this paper, child means an individual aged less than 18 years. Specialised literature terms the adults who grow up in such a family as adult children of addicted parents. This term encompasses the explanation that the early childhood experience has such an impact on those children that their lives would continue to always relate to this experience to some extent. In Slovakia and the Czech Republic, we have solid publications which make use of case studies and describe the feelings of such children when they grow up (Woititzová, 1998; Uehlinger \& Tschui, 2009).

Within the KIDS STRENGTHS project: Kids in the Context of Mental Vulnerability (2009-1-AT-LEO05-01199), that was implemented on an international basis from 20082011, we focused on children in the context of a parental mental disorder which also included parental substance abuse. The project focused on the development of the theoretical background important to understand the topic and on the development of interventions by various experts. Documents for teachers, special teachers, social workers, therapeutic teachers and other experts are available on the web site of the project in several languages, including in the Slovak language (www.strong-kids.eu).

\section{Description of a family with an addicted parent}

Multiple research works have identified certain common features of families with an addicted parent that may be generalised and considered to be typical. Even though they may not necessarily be equally found in all families, such features (CASA, 2005) include:

- stress caused by frequent conflicts;

- inconsistent, poor up to neglectful parenting;

- unclear rules;

- unclear definition of roles and constant changes of rituals.

In their review of specialised literature, Solis et al. (2012) found other features which supplement the above list:

- addicted mothers show less warmth, apply harsher parenting style, shows less physical and verbal engagement in communication with the child than non-addicted mothers;

- addicted fathers are less sensitive to child's needs and less engaged in parenting;

- parental substance abuse, whether on the side of the mother or the father, is associated with higher risk of child abuse or neglect. 
Similar findings have also been identified by the experts of the AAETS organisation (2014). The behaviour of addicted parents is often unpredictable for the child, there are no rules of conduct in the family or the rules are inconsistent and depend on the quantity of alcohol drunk, which pre-school children are unable to understand, and if the parent behaves so, it confuses or scares them.

Children of addicted parents find themselves in situations in which they see their parent lying helpless and unable of any movement or communication. They happen to be forgot or dumped by a parent with another person, or parents leave the house and children are left at home alone to their fate for a long time (Modul 2, 2010). Therefore, exposure of a child to these situations that the child is unable to understand at certain age or interpret them correctly affects their development and compels children to cope with them in their own way.

Roles in these families are not clearly defined, the life of the family is often chaotic, disorganised and difficult to predict. Many families fall into poverty both due to the cost of the addictive substance and due to the inability of parents to keep their job and behave appropriately at work. Disrupted relations often continue when the child grows up, and some children even cut off all contact with the addicted parent for good (Schäfer, 2011).

\section{Features of a child of an addicted parent}

Solis et al. (2012) note that compared to the intact children, the children of addicted parents have worse school results, have problems in emotional and social area and behaviour, and rarely have the so-called secure parental attachment. This is sometimes believed to stem from poverty or poorly stimulating environment in which they are raised and which is typical for worse parental skills. The CASA report (2005) states that grandparents or other persons in child's neighbourhood often take up an important role in the life of a child of addicted parent, because the parent is unable to make the child feel safe and take care of him or her.

Considering the medical, family and social history of the child, children growing up in a family with an addicted individual can be classified as the so-called mentally vulnerable children. The concept of mental vulnerability emerged in the 1960s in response to the question whether it is possible to identify individuals who are more predisposed to mental health problems. It can hence be taken as the predictor of mental health or mental illness, as the case may be (Eplov et al., 2010). The higher the scores, the higher the risk of mental disorder prevalence. Rutter (1979) identified 6 risk factors which lead to the development of the so-called mentally vulnerable child:

- major marriage problems;

- low social and economic status;

- father engaging in criminal behaviour;

- large family/overcrowded household;

- mental disorder in mother;

- child placement in foster care. 
The category of children showing high probability of mental health problems includes children with mostly negative experiences in life - originally children with behavioural disorders, learning disorders, and with a long-term illness, but also children growing up in foster care who have experienced trauma, abuse or neglect, poverty, malnutrition, or children exposed to violence in war conflicts (Green \& Solnit, 1964). Our prior research work showed that this category also includes children with ADHD and other special education needs (Dubayová, 2015; Dubayová \& Chovanová, 2017). Mental vulnerability in children can be observed through a great variety of behaviours which can be so specific for this or that child that their diversity makes the diagnostic process more difficult. Symptoms that may be observed in a mentally vulnerable child include, for example, disobedience, engagement in fights, stealing, but also anxiety, shyness, eating disorders, tearfulness. Some may suffer from anger fits, bizarre manners or self-injury (Kožárová \& Podhájecká, 2014). The longitudinal research work of Drake and Vaillant (1988) confirmed that children of alcoholic parents are more likely to become patients of psychiatric hospitals, because they are exposed to a bigger risk of mental disorder as, for example, depressions or personality disorders, than the intact children.

Research studies of US researchers also point out that these children are more likely to become victims of violent crimes than the other children. Such violence stems from highconflict and, from the perspective of relations, dysfunctional environment, or the children witness violence. In their adult life, they are at the threat of re-victimisation. Even though they matured and left their primary environments, they are very probable to establish partnerships copying the patterns in which they were growing up and become victims again (AAETS, 2014). The consequences of life with an addicted adult have various impacts on further development of the child. As Pretis and Dimova (2004) provide, this particularly depends on

- the age at which the child was exposed to violence;

- intensity of symptoms (addiction) in the parent;

- sex of the parent (alcoholism in mothers has a stronger impact on child's development).

They also more often suffer from health problems on a psychosomatic basis, e.g. headaches, stomach aches, sleeping disorders, etc. Conners et al. (2003) made a comparison between intact children and 4,089 children of addicted mothers, and found differences in the area of health difficulties. Children of addicted mothers were twice as common as intact children diagnosed asthma, hearing issues were three times as common as in their intact peers, and vision issues were seven times as common (Conners et al., 2003).

Specific features in these children have also been observed in the social area. AAETS (2014) assert that these children are more socially shy than the intact population. They have difficulty to make friends both because they lack social skills and because they are unable to confide and share information about parents, which makes them be on guard. The Christoffersen's and Soothill's research work (2003) confirmed that father's alcoholism 
is a factor playing role in child mortality and mother's alcoholism is associated with child neglect and abuse, and increases the probability that the child commits a violent crime at older age.

Such a dramatic impact on a child has not been observed in every single family. The impact on the child strongly depends on the degree of parental addiction and compensatory effects of other family members or neighbourhood (e.g. if only one parent drinks, if the parent is able to compensate for the time when he or she is drunk with more attentive care for the child when sober, if the child has enough social contacts, etc.).

\section{Recommendations for practice and intervention}

Help to children of addicted parents at special teacher's offices takes place in the context of a formal and official framework of help which is defined by expert activities within his or her profession: diagnostics, counselling, prevention, rearing and education, special pedagogy intervention, re-education and rehabilitation. Experts' contacts with the child may also be informal, e.g. he or she may be a neighbour of such a family, or can meet the child at informal events, etc.

System solutions aiming to help children at risk in each developed society exist, for example, in the form of crisis centres, foster care system, professional parenting, family recovery efforts, monitoring by the Office of Labour, Social Affairs and Family, etc. The question, however, is how efficient these system measures are and which of the child's needs they satisfy. This paper rather focuses on the methods which are based on personal engagement of helping individuals and sometimes also become formal taking the form of civic activities or associations.

Support groups which bring together people who have gone through similar experiences constitute a method which helps them to cope with the experiences of life with an addicted parent. The support from people who have faced similar problems has a particularly strong therapeutic effect. They apply the principles of group dynamics and professional therapeutic leadership. The Adult Children of Alcoholics (ACA) in the United States of America is one of the support groups with a solid and long history. The USA have a quite extensive and differentiated network of support groups, e.g. Families Anonymous (support of families and individuals close to addicted people), Alateen (for adolescents of addicted parents), National Association for the Children of Alcoholics (NACOA), etc. For more information about individual support groups, refer to the list of Adfam organisation which helps families with an addicted individual (http://www.adfam. org.uk/families/useful_organisations).

Recommendations for experts have been drawn within the Kids Strengths project (Module 2, 2010) which should be remembered in contact and when helping a child with an addicted parent:

- need to create a safe zone or background that will satisfy the child's basic needs. Contact with other individuals and preventing social isolation of the child will help him or her to gain healthy social habits and reduce the feelings of loneliness. 
- creation of a social network of stable and healthy individuals who would listen to child's worries. The role of these individuals also is to be a role model for healthy behaviour, to provide emotional support to the child, take care of the development of healthy self-assessment, point out child's successes and allow the child to be a child.

- if necessary, arrange for foster care in the place of child's residence, if possible. This measure is important particularly when the child's basic needs are at risk; these include, for example, nutrition, safety, school attendance, etc. Breaking close relationships with peers and school or teachers that the child has already established may cause another trauma, and therefore, if it's only possible, these ties should be kept.

- create clear boundaries for behaviour in the event of contact with a parent when intoxicated. Establishment of the rules for contact, taking care of child's safety in such moment and their consistent observance are supportive for the child, be cause they clearly define his or her rights, obligations and expected behaviour. They also take off the burden of responsibility from the child with regard to the care for intoxicated parent.

The rule that has been mentioned only marginally, but which should be taken into consideration at any intervention during work with a child of an addicted parent, is that the child should not be presented as the one who is responsible for the parent's addiction or abstinence. On one hand, this rule protects the child from assuming responsibility for a condition that the child cannot influence, and also helps the addicted individual to realise the responsibility for his or her own conduct and not transfer it to other people. Just like certain factors, such as mental health of parent, intensity of deprivation or exposure of the child to violence, are associated with mental vulnerability, so other factors have protective function and help to build resilience, i.e. mental strength in a child. Protective factors preventing development of issues in a child include (Rutter, 1990; Massad et al., 2009; Solis et al., 2012):

- mother's education - higher education is associated with higher ability to cope with distress;

- good relationship between the mother and the child;

- good relationships in the family;

- key event in life, some important decision, e.g. staying at school, keeping unwanted child;

- supporting positive self-esteem and self-confidence;

- safe and supporting social contacts with other individuals;

- ability to complete duties - feeling good about it;

- strong positive experience that gives strength to the child and positive self-esteem;

- open future - existence of the opportunities for development, work, career;

- good relationship to another individual, e.g. parent who is not addicted, grandparents or teachers is helpful for children raised by one addicted parent. 
The last point relates to an effective form of mentoring assistance. The mentor's function is to provide emotional and psychological support to the mentee and help him / her feel welcome, accepted and integrated (Hobson, 2012; Dubayová \& Kochová, 2016). The professionalization of volunteer activities, availability and awareness raising about the problem is the common denominator for the above options and recommendation. In conclusion, I would like to emphasize that personal engagement of the neighbourhood that notices and helps the child is more worthwhile than all system solutions together. We need to realise that these children are all around us, that we meet them in our personal lives and often do not have the slightest idea about what they have gone through - all this forms the foundations for assuming personal accountability for the phenomena happening around us and that we as individuals, and not just as experts, can help to change the life of another human for the better.

This paper was written within solution of the Analysis of Roma University Students Narratives - Examples of Good Practice of Mentoring project (No. 21830131) with the support of the International Visegrad Fund.

\section{References}

AAETS (The American Academy of Experts in Traumatic Stress). (2014). Effects of parental substance abuse on children and families. Retrieved May 19, 2019, from http://www. aaets.org/article230.htm

CASA (The National Center on Addiction and Substance Abuse at Columbia University). (2005). Family matters: Substance abuse and the American family. New York: CASA.

Christoffersen, M. N., \& Soothill, K. (2003). The long-term consequences of parental alcohol abuse: a cohort study of children of Denmark. Journal of Substance Abuse Treatment, 25(2), 107-116.

Conners, N. A., Bradley, R. H., Mansell, L. W., Liu, J. Y., Roberts, T. J., Burgdorf, K., \& Herrell, J. M. (2003). Children of mothers with serious substance abuse problems: an accumulation of risks. The American Journal of Drug and Alcohol Abuse, 29(4), 743-758.

Drake, R. E., \& Vaillant, G. E. (1988). Predicting alcoholism and personality disorder in 33-year longitudinal study of children of alcoholics. British Journal of Addiction, 83(7), 799-807.

Dubayová, T. (2015). Mental vulnerability as a factor of school performance in pupils of young school age - report from pilot study. Annals of Psychiatry and Mental Health, 3(3), 1028-1030. 
Dubayová, T., \& Chovanová, E. (2017). Mental health of pupils with ADHD in Slovak republic - a pilot study. In Zborník príspevkov z medzinárodnej vedeckej konferencie EDULEARN17, 3.-5. júl, Barcelona, Španielsko (pp. 8463-8467).

Dubayová, T., \& Kochová, H. (2016). Mentor ako facilitátor školskej úspešnosti žiakov z rómskeho etnika na strednej škole. Prešov: Roma Education Fund.

EMCDDA (European Monitoring Centre for Drugs and Drug Addiction). (2010). Children's voices: experiences and perceptions of European children on drug and alcohol issues. Luxembourg: The Publications Office of the European Union.

Eplov, L. F., Petersen, J., Jørgensen, T., Johansen, C., Birket-Smith, M., Lyngberg, A. C., \& Mortensen, E. L. (2010). The mental vulnerability questionnaire: a psychometric evaluation. Scandinavian Journal of Psychology, 51(6), 548-554.

Green, M., \& Solnit, A. J. (1964). Reactions to the threatened loss of a child: a vulnerable child syndrome. Pediatrics, 34(1), 58-66.

Hobson, A. J. (2012). Fostering face-to-face mentoring and coaching. In S. J. Fletcher, \& C. A. Mullen (Eds.), The SAGE Handbook of Mentoring and Coaching in Education (pp. 59-73). Thousand Oaks (CA): SAGE Publication.

Kožárová, J., \& Podhájecká, M. (2014). Dieta v predškolskom veku s problémovým správaním - prevalencia a faktory podmieňujúce jeho vznik. Špeciálny pedagóg, 3(1), $16-25$.

Massad, S., Nieto, F. J., Palta, M., Smith, M., Clark, R., \& Thabet, A. (2009). Mental health of children in Palestinian kindergartens: resilience and vulnerability. Child and Adolescent Mental Health, 14(2), 89-96.

Modul 2. (2010). Vplyv tažkostí v oblasti duševného zdravia rodičov na deti. Retrieved May 19, 2019, from http://www.strong-kids.eu/index.php?menupos=7

Pretis, M., \& Dimova, A. (2004). Frühförderung bei Kindern psychisch kranker Eltern. München: Ernst Reinhardt Verlag.

Rutter, M. (1979). Protective factors in children's responses to stress and disadvantage. In M. W. Kent, \& J. E. Rolf (Eds.), Primary Prevention of Psychopathology: Social Competence in Children (pp. 49-74). Hanover: University Press of New England.

Rutter, M. (1990). Psychosocial resilience and protective mechanism. In J. Rolf, A. S. Masten, D. Cicchetti, K. H. Nüchterlein, \& S. Weintraub (Eds.), Risk and protective factors in the development of psychopathology (pp. 181-214). Cambridge: Cambridge University Press. 
Schäfer, G. (2011). Family functioning in families with alcohol and other drug abuse. Social Policy Journal of New Zealand, 2011(37), 1-17. Retrieved May 19, 2019, from https:// www.msd.govt.nz/about-msd-and-our-work/publications-resources/journals-and-magazines/social-policy-journal/spj37/37-family-functioning-in-families-with-alcohol-and-other-drug-addiction.html

Solis, J. M., Shadur, J. M., Burns, A. R., \& Hussong, A. M. (2012). Understanding the diverse needs of children whose parents abuse substances. Current Drug Abuse Reviews, 5(2), 135-147.

Uehlinger, C., \& Tschui, M. (2009). Když někdo blízký pije. Praha: Portál.

Vašek, Š. (2011). Základy špeciálnej pedagogiky. Bratislava: Sapientia.

Woititzová, J. G. (1998). Dospělé děti alkoholiků. Praha: Columbus.

\section{Author}

Mgr. Tatiana Dubayová, PhD.

Faculty of Education, University of Prešov

Department of Special Education

Ul. 17. novembra 15, 08001 Prešov, Slovak Republic

tatiana.dubayova@unipo.sk 